Journal of Business and Tourism

Volume 05 Number 01

January - June, 2019

\title{
Examining The Social Impact of Microfinance on Poverty Reduction
}

\author{
DR. SAIF UL MUJAHID SHAH \\ Universiti Malaysia Sarawak (UNIMAS), Malaysia \\ saifshah86@gmail.com \\ DR. ANWAR UL MUJAHID SHAH \\ Lecturer, Department of Sociology \\ Bacha Khan University Charsadda (BKUC) \\ anwarids@yahoo.com \\ SYED ARSHAD ALI SHAH \\ Lecturer, Department of Management Science \\ Bacha Khan University Charsadda (BKUC), corresponding \\ :arshad@bkuc.edu.pk.com
}

\begin{abstract}
As Poverty has become a global challenge for all the nations around the world, from the past many years, different strategies have been used to reduce it. However, since 1980s Microfinance has become a powerful tool to alleviate poverty and it's not adopted even in the developing countries but also developed nations have been practicing it. Many of the past studies used the economic indicators to measure the impact of microfinance on poverty reduction, and few have concentrated on the social indicators. The purpose of this research is to examine the effect of microfinance as a poverty reduction in terms of social indicators in the rural areas of northern Khyber Pakhtunkhwa, Pakistan. The objective of this research is to check whether the established NGOs in the concern areas have been successful in bringing social change in the life of the beneficiaries. For the purpose of analysis, the structural equation model is applied to a sample of 440 collected through a structured questionnaire. Results show that microfinance had a negative impact on the health and education of the beneficiaries. This research indicates that more funds and priority should be given to the education and health sector because they have equal importance as compared to the other economic indicators.
\end{abstract}

Key Words: Microfinance, Social Indicators, poverty, Khyber Pakhtunkhwa

\section{Introduction}

The roots of poverty arespread across the globe and have become a global challenge for world leaders to improve the wellbeing of the poor masses and achieve sustainable development in developing countries.In this regard, variouspoverty alleviation programs/ approaches have been adopted with time by different governments, policymakers and practitioners such as reducing population growth, enhancing education and health conditions, creating employment opportunities, reducing inequality and empowering women(Farag, 2011). In the new area microfinance is considered to be the powerful tool 
for reducing poverty and many governments have adopted the policy of Grameen bank, which is the milestone of all the microfinance that are being initiated in the whole world today. In the past three decades, the popularity of microfinance has been increased as a good strategy for alleviating poverty (De Goey, 2012). The emergence of microfinance has attracted not only national attention, but also global attention and has dramatically changed the living standard of the poor (Sawada et al., 2018). The global attention can also be realized from the fact that the number of borrowers reached 211 million in 2013 as compared to 13 million customers (Morduch, 2017).

As the major challenge in the developing countries to low-income people is the lack of financial resource, which acts as a hindrance to the improvement in their living standard (Kono \& Takahashi, 2010).Microfinance has become a tool for alleviating poverty from the poor who are unable to get capital from the banks due to collateral. In simple terms, microfinance is a provision of financial services to the poor people who are unable to get finance from the commercial banks for setting up a small scales business (SainzFernandez et al., 2015). According to Wright (2000), more research is neededregarding the impact of microfinance on social indicators as little research that has been conducted on such interventions. According to Premchander (2003) due to absent of microfinance on the social indicators such as health education, and human resource, the entire effort in the field of Microfinance may turn out to be null.Similarly, most studies have focused the economic aspects of wellbeing regarding microfinance (Pitt \& Khandker, 1998; Morduch \& Hashemi, 2003; Goldberg (2005); Nawaz 2010; Amin et al., 2010; Imai \& Azam, 2012; Angelucci et al., 2013). Limited studies have been conducted on health and education (Wydick,1999; Holvoet, 2004; De Mel et al., 2009; Brau et al., 2009; Dupas et al., 2013). Particularly in the context of Pakistan, only a few studies have been conducted (Noreen et al., 2011; Ghalib et al. 2011: Shirazi, 2012). So this study will add to the existing body of knowledge in Pakistan related tothe impact of microfinance.

\section{Literature Review}

The past lecture is more focused on the economic indicators (Pitt \& Khandker, 1998; Morduch and Heshemi 2003; Goldberg, 2005; Nawaz, 2010; Amin et al., 2010; Armendariz \& Morduch, 2010; Amin et al., 2010; Durrani et al., 2011; Li et al., 2011; Imai \& Azam, 2012; Nghiem et al ., 2012; Angelucci et al., 2013; Augsburg et al., 2015; Fofana et al., 2015; Khandker \& Koolwal, 2016) in many of the Studies saving, income and assets are used as proxy indicators to measure the impact of poverty on microfinance (Mina and Alam, 1995; Mk Nelly and Dunford 1998; Khandker, 1998; Panjaitan et.al, 1999; Remenyi \& Quinones., 2000; Rahman et al., 2001; McKerman, 2002; Azam \& Imai, 2009; Abou-Ali et al., 2009; Siwar et al., 2011; Ahmed et al., 2011; Saad, 2011; AlMamun et al., 2011; Al Mamun et al., 2012). Similarly, very few studies have been conducted on the socio indicators Wydick,1999; Holvoet, 2004; Dunford, 2006; Nghiem et al., 2007; Brau et al., 2009; Verpoorten, 2009; De Mel et al., 2009; Das, 2012, Augsburg et al., 2012; Dupas et al. 2013; Tarozzi et al., 2015). Likewise, Wydick (1999) examined the impact of microfinance on children education in Guatemala and found that most of the beneficiaries children were enrolled in schools and they were being stopped of doing laboring for their families. A similar study was carried by Stark et al. (2015) by considering four indicators health, childcare, education, and consumption by employing Quasi-experimental design and found a non-significant effect on all indicators as 
compared to beneficiaries. The researcher advocated spending more on the social programmes then the economic indicators, so that changed can be brought in the social status of the beneficiaries. Bose, (2017) carried out a study in Kerala, India, and found that microfinance has improved their social status inform of improvement in health and education. Similar results were reported by Brau et al., 2009; Holvoet, (2004); Singh \& Singh, 2014. Also, Roy \& Biswas (2016) examined the impact of microfinance organization Bangladesh and revealed a positive effect on the social indicators. Ali et al., (2016) conducted a study in examined in several countries in Asia, Africa, Latin America, and Europe on the role of microfinance in poverty alleviation and reveal an improvement in nutrition, better health, and education and employment opportunities.

Similarly, Pitt \& Khandker (1998) studied Grameen microfinance loan in Bangladesh and found a positive impact on the family education, household expenditure and nutrition. Likewise, Karim (2017) study also confirm that microfinance had improved the socioeconomic status of the borrowers. The borrowers were able to finance their children schooling, the children enrollment in the school increased, and they were also able to get self-employed. In short, microfinance was able to promote education, health, and to empower women. Similarly, Tu et al., 2015 evaluated the impact of a microfinance program on socio-economic development in Vietnam. The results show a positive effect on the socioeconomic indicators. Similarly, Butcher (2010), also conforms a positive impact of microfinance on the clients and enhanced their economic status.

Similarly, in the context of Pakistan, few studies have been conducted on social indicators. As the majority of the studies like Khandker and Faruque (2001; Saboor et al. 2009) have focused on the economic aspects of the impact of microfinance on poverty. On the contrary, very few studies in Pakistan have studied the social side of the microfinance like Noreen et al. (2011) found a positive impact on the social indicator like education of the beneficiaries. Likewise, Ghalib et al. (2011) researched the impact of microfinance and revealed a positive impact on health care expenditures, similar views were found in the study conducted by Shirazi, 2012.

\subsection{Hypotheses Development}

\subsubsection{Education}

Education is viewed as a base for improvement of economic growth and a useful tool for poverty mitigation (Hytopoulos, 2011). Hashemi (1996) is of the view that the provision of non-financial service, such as education will make the microfinance more effective in utilizing the loan more productively. Microfinance is a better mechanism that facilitates the poor in accessing capital and developing income-generating activities that consequently increase their income. The increased income will be used on the expenditure of their family health care,children education, and nutrition (Chowdhury \&Mukhopadhaya, 2012). The past studies that have used education as proxy for impact including Johnson and Rogaly, 1997; Morduch, 1998; Coleman, 1999; Holvoet, 2004; Montgomery, 2005; Zaidi et al. 2007; Chemin, 2008; Kondo et al., 2008; Thibbotuwawa et al. 2012; Crepon et al., 2015; Tarozzi et al., 2015; Attanasio et al., 2015; Banerjee et al., 2015; Angelucci et al., 2015) have found positive impact of education of the microfinance recipients and their families. 
Moreover, microfinance interventions in most studies have been showing a significant impact on education. Roy \& Biswas, (2016) researched the impact of microfinance on the socio-economic changes in the rural community of Bangladesh and found that microfinance play key role in promoting education and reducing dropouts rates from educational institutions. Similarly, Holland and Wang(2011); Maldonado and GonzálezVega (2008); Banerjee et al. (2013) explored the impact of microfinance on educational outcomes and revealed significant impact on education and poverty reduction likewise Littlefield et al.(2003), also witnessed a positive impact of microfinance on the children education of the beneficiaries. Thus, creating access to education is one area of intervention under the poverty reduction strategy.Therefore, we hypothesise that:

H1: Access to microfinance has a significant positive impact on the education of the households

\subsubsection{Health}

Health is one of the critical areas of non-financial impact of microfinance on poverty Wright (2000). Karlan and Morduch (2010) are of the view that microfinance's financial interventions only are not effective in reducing poverty; rather, it should be coupled with other social interventions such as health and training. Number of past studies used health as an indicator for measuring the effect of microfinance on poverty (Wright 2000; Morduch \& Haley 2002; Duflo, 2003; Dupas \& Robinson, 2008; Adjei et al., 2009; Stewart et al., 2010; Odell, 2010; Zinman, 2010; Brannen, 2010). The impact of microfinance on poverty regarding the health indicator is considered necessary. A study conducted by Leatherman and Dunford (2010) revealed a positive relationship between health and microfinance by reducing poverty in the form of providing services such as social protection and financial security. Subsequently, a research study in Morocco by Crepon et al. (2011) also showed a likely increase in health spending with the emerging of microfinance projects in the area. Similar results were achieved by McNelly and Dunford, (1999); Banerjee et al. (2009), Dupas and Robinson (2013); Stewart et al., (2010) regarding microfinance as an effective tool in supporting health related expenditures. Littlefield et al. (2003) also acknowledged the importance of microfinance intervention in the health facilities and conformed the notion that micro finance beneficiaries have better health practices and nutritional level as compared to nonbeneficiaries. In order to know the significant impact of microfinance on beneficiaries, the following hypothesis is developed.

H2: Microfinance loan granted to households has no effect on their health expenditure

\subsubsection{Empowerment}

Empowerment is also one of the social indicators to measure the impact of microfinance on poverty. Empowering a poor means to gain control over the resources and making family decisions independently and participating in community decisions. In recent times poverty is not only attributed to the absence of income and other resources but it also due to lack of autonomy and dignity which can be achieved through human empowerment (Cagatay, 1998; Hussain and Mahmood, 2012). According to Gutierrez (1990, p. 149), "Empowerment is a process of increasing personal, interpersonal, or political power so that individuals can take action to improve their life situation." 
The main objective of microfinance is to empower the marginalized people and help them in sustaining their flow of income and making them economically independent (Guerin \& Palier, 2005). The study which was conducted in 16 different microfinance organizations from all over the world by Robinson (2001) concluded that the beneficiaries' standard of living was improved and they gained more self-confidence and dignity in their respective societies. Similarly, Lont and Hospes (2004) found in their research study that most of the microfinance organizations in Asian countries have a positive impact on the empowerment. Similar views were also observed by Goetz and Gupta, 1994; Johnson \& Rogaly, 1997; Mayoux, 1999; Ledgerwood, 1999; Carlton et al., 2001; Narayan, 2002; Lakwo, 2006; Dobra, 2011. In short, microfinance has played an important role in the empowerment of the poor in the form of enhancing their self-esteem and making a decision independently (Al-Shami, et al 2013). In this regard, the following hypothesis was tested through structural equation modeling.

\section{H3: Microfinance has a Significant Impact on Empowerment}

\subsubsection{Employment}

According to Weber (2006 p.50), the link of microfinance to poverty alleviation is "the provision of small loans to individuals, usually within groups, as capital investment to enable income generation through self-employment." In the developing economies, the primary cause of poverty is unemployment and underemployment (Sodipe \& Ogunrinola, 2011) and the basic reason for lack of employment opportunities is the non-availability of funds (Bhuiya, 2016). In this regard, microfinance is one of the key elements that provide finance to the poor and support them in developing the small business so that they become self-employed and contribute to the national development (CGAP, 2010). Due to lack of resources, most of the developing countries rely on the microfinance institutions for creations of the employment opportunities as it believed that microfinance institutions could create job opportunities (Jackson \&Islam, 2005). According to Lont and Hospes, 2004,) microfinance has the ability of transformation from the vicious circle of poverty into a virtuous cycle of economic development. Likewise, Zeller and Sharma (1998) also argue that microfinance has the ability to help needy families in establishing family enterprises and providing an economically secure life.

A study carried out in Pakistan by Iqbal et al. (2015a) on the impact of microfinance on poverty conforms that microfinance has a positive impact on the creation of employment in the intervention areas of the project and their standard of living has improved after receiving the loan. Similarly, Meyer (2010) observed that microfinance could reduce poverty by supplying loans and creating job opportunities. Likewise, Crepon et al. (2015) reported that in rural Morocco microfinance organizations generated a significant impact on the employment activities, and most of the beneficiaries were self-employed in different sectors. In regards to employment, the following hypothesis was developed in order to know the impact of microfinance on employment.

H4: Microfinance has a significant impact on employment.

\section{Sampling and data collection}

The study was carried out in the Northern Areas of Pakistan to measure the social impact of microfinance borrowers. A total of 468 respondents were interviewed from three NGOs in the study, namely the Integrated Chitral Development Programme, Karimabad Area Development Organization, and Garamchashma Area Development Organization. 
Quazi expermentl design was used to evaluate the impact. Random sampling was used to select the participant from each NGO. Structural equation model was used to examine the impact of microfinance on the social indicators, and Smart Pls is used as a tool to analyse the data.

\section{Findings}

\subsection{Assessment of the measurement model}

To test the reliability of items, discriminant validityand convergent validity of the measurement scales, confirmatory factor analysis was used. Table 1 has all the items have loadings above the minimum critical point of 0.50 (Bagozzi et al., 1991), which conforms criteria of internal consistency. The convergent validity is confirmed through the composite reliability, which is also above the threshold of 0.7 suggested by Chin (2010). The internal consistency of the items was checked through Average variance extracted (AVE), which are above the criteriaof 0.50 (Hair et al., 2013). HeterotraitMonotrait (HTMT) is used to compute discriminant validity. For discriminant validity (refers to Table 2), following the HTMT criterion, the valueis below HTMT.90 (Henseler et al., 2015). Hence, the measurement model was satisfactory and provided sufficient evidence in terms of reliability, discriminant validity and convergent validity.

Table 1: Results of Measurement Model

\begin{tabular}{|c|c|c|c|c|}
\hline Constructs & items & Loadings & $\mathrm{CR}$ & AVE \\
\hline \multirow[t]{4}{*}{ Education } & $\overline{E d u 2}$ & 0.773 & 0.852 & $\overline{0.594}$ \\
\hline & Edu3 & 0.799 & & \\
\hline & Edu4 & 0.598 & & \\
\hline & Edu5 & 0.886 & & \\
\hline \multirow[t]{5}{*}{ Employment } & Employ1 & 0.923 & 0.900 & 0.655 \\
\hline & Employ2 & 0.936 & & \\
\hline & Employ3 & 0.95 & & \\
\hline & Employ4 & 0.523 & & \\
\hline & Employ5 & 0.608 & & \\
\hline \multirow[t]{6}{*}{ Empowerment } & Empov2 & 0.84 & 0.912 & 0.634 \\
\hline & Empov4 & 0.783 & & \\
\hline & Empov5 & 0.843 & & \\
\hline & Empov6 & 0.769 & & \\
\hline & Empov7 & 0.686 & & \\
\hline & Empovs3 & 0.846 & & \\
\hline \multirow[t]{5}{*}{ Health } & Health2 & 0.897 & 0.943 & 0.772 \\
\hline & Health3 & 0.973 & & \\
\hline & Health4 & 0.964 & & \\
\hline & Health5 & 0.91 & & \\
\hline & Health7 & 0.596 & & \\
\hline \multirow[t]{5}{*}{ Interest } & Interest 1 & 0.652 & 0.903 & 0.653 \\
\hline & Interest 2 & 0.822 & & \\
\hline & Interest3 & 0.833 & & \\
\hline & Interest7 & 0.907 & & \\
\hline & Interest8 & 0.803 & & \\
\hline Supervision & Supv1 & 0.685 & 0.884 & 0.609 \\
\hline
\end{tabular}




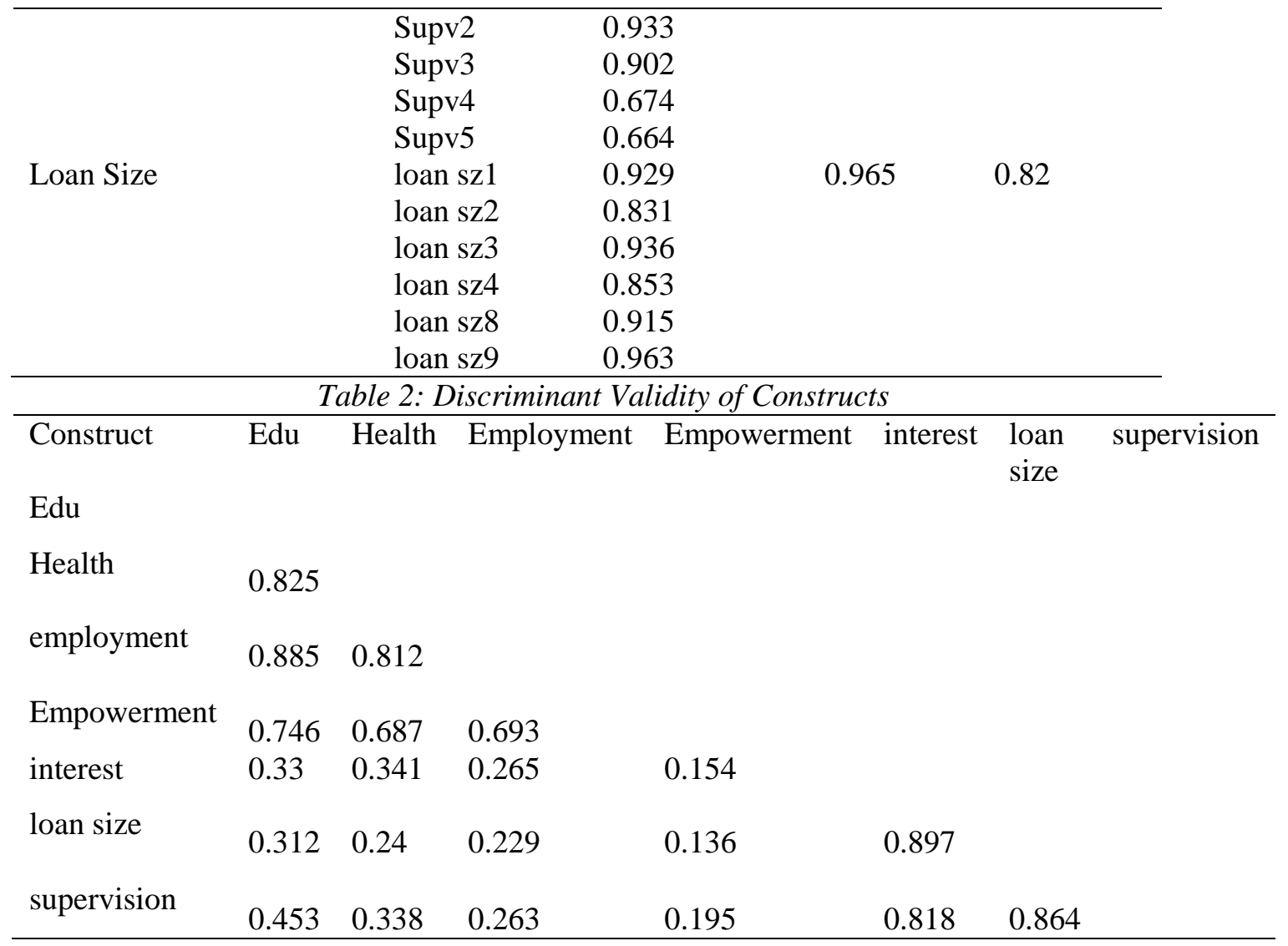

Table 3 depicts the assessment of the Structural Model. The results show that out of 4, two hypotheses are significant. Microfinance has an impact on the employment and empowerment of the beneficiaries while there is a non-significant impact on the beneficiaries education and health.

Table 3: Path Coefficients and Hypothesis testing

\begin{tabular}{llllll}
\hline Hypothesis & Relationships & $\begin{array}{l}\text { Standard } \\
\text { Beta }\end{array}$ & $\begin{array}{l}\text { Standard } \\
\text { Error }\end{array}$ & t- Value & Support \\
& & & & \\
\hline H1 & Microfinance -> Health & 0.282 & 0.168 & 1.68 & N0 \\
H2 & Microfinance -> Education & 0.312 & 0.246 & 1.27 & No \\
H3 & Microfinance -> Empowerment & 0.450 & 0.119 & 3.797 & Yes \\
H4 & Microfinance -> Employment & 0.275 & 0.134 & 2.057 & Yes \\
\hline
\end{tabular}

5. Summary and conclusion

The study was carried out in the northern areas of Pakistan. The main purpose was to analyze the social impact of microfinance on poverty using social indicators, including employment, empowerment, health, and education. The data was collected from three NGOs, namely Integrated Chitral Development Programme, Karimabad Area Development Organization, and Garamchashma area Development Organization. The non- parametric approach was used toevaluate the impact. The study suggests that more 
importance should be given to the social sectors as only focusing on the economic indicators is not enough. The impact of microfinance on the socio indicators is partial, as only empowerment and employment are significant while the remaining indicators are seeming to be non-significant. The non- significant of the health indicators are inclined with the past studies (Angelucci et al., 2012; De Mel et al. 2009; Crepon et al., 2015; Banerjee et al., 2015) similarly the non-significant results of education are consistent with past literature (Adjei et al., 2009; Shimamura \& Lastarria-Cornhiel, 2010; Islam \& Choe, 2013). which means that microfinance impact on education and health was small and the possible explanation is that the people in the area gave less importance on education and they couldn't afford education expenses. The case is similar for health as most of the people were poor and thus reluctant to spend on health unless they experienced severe health conditions. Employment and empowerment had a positive impact on microfinance. The positive impact of empowerment was consistent with the previous literature (Hashemi et al., 1996; Borchgrevilk et al., 2005; Swain, 2006; Ayuub, 2013; Weber and Ahmad 2014; Rathiranee \& Semasinghe, 2015; Buvinic \& Furst-Nichols, 2016) while the significance of self-employment opportunities were also in line with the past studies conducted by Adugna and Heidhues, 2000; Gomez and Santor, 2001; Wydick, 2002; Banerjee et al., 2010; Bisirat, 2011; Crepon et al., 2011 Crepon et al., 2015; Khan and Rahman, 2016.

\section{Reference}

Abou-Ali, H., El-Azony, H., El-Laithy, H., Haughton, J. \& Khandker, S. R. (2009). Evaluating the Impact of Egyptian Social Fund for Development Programs. Policy Research Working Paper 4993.

Adhikari, D. B., \& Shrestha, J. (2015). Economic impact of microfinance in Nepal: A case study of the Manamaiju Village Development Committee, Kathmandu. Economic Journal of Development Issues, 15(1-2), 36-49.

Adjei, JK, Arun, T \& Hossain, F (2009). 'The Role of Microfinance in Asset-Building and Poverty Reduction: The Case of Sinapi Aba Trust of Ghana', University of Manchester.

Aigbokhan, B. E. (2008). Growth, inequality and poverty in Nigeria. Prepared for United Nations Economic Commission for Africa (UNECA). Addis Ababa, Ethiopia. Retrieved 2017-04-25 from: http://repository.uneca.org/handle/10855/14927

Ali, A. and M. A. Alam (2010), Role and performance of microcredit in Pakistan. Master's thesis in International Business, Department of Economics and Informatics, University West, pp. 1-43.

Ali, M., Saeed, G., Zeb, A., \& Jan, F. A. (2016). Microcredit \& its Significance in Sustainable Development and Poverty Alleviation: Evidence from Asia, Africa, Latin America and Europe. Dialogue (Pakistan), 11(3).

Amin, R., Shah, N. M. \& Becker, S 2010, 'Socioeconomic factors differentiating maternal and child health-seeking behavior in rural Bangladesh: A cross-sectional analysis', Int J Equity Health, vol. 9( 9), pp. 1-12.

Angelucci, M., Karlan, D., \& Zinman, J. (2013). Win some lose some? Evidence from a randomized microcredit program placement experiment by Compartamos Banco. IZA Discussion Paper, No. 7439. 
Arif, G. M. (2006). Targeting Efficiency of Poverty Reduction Programs in Pakistan. Working paper No. 4, Asian Development Bank.

Armendáriz de Aghion, B., \& Morduch, J. (2005). The Economics of Microfinance MIT Press. Cambridge, Massachusetts.

Armendáriz, B., \& Morduch, J. (2010). The economics of microfinance. Cambridge, MA: MIT Press.

Augsburg, B., De Haas, R., Harmgart, H. \& Meghir, C. (2012). Microfinance at the margin: experimental evidence from Bosnia and Herzegovina. European Bank for Reconstruction and Development- Working Paper, No.146.

Augsburg, B., De Haas, R., Harmgart, H., \& Meghir, C. (2015). The impacts of microcredit: Evidence from Bosnia and Herzegovina. American Economic Journal: Applied Economics, 7(1), 183-203.

Awan, M. S., Malik, N., Sarwar, H., \& Waqas, M. (2011). Impact of education on poverty reduction. International Journal of Academic Research, 3(1), 659-664. Retrieved 2017-03-23.

Azam, S. \& Imai, K. S. (2009). Vulnerability and poverty in Bangladesh. Chronic Poverty Research Centre, Working Paper, 141

Barnes, C., Gary, G. \& Richard, K. (2001). Impact of Three Microfinance Programs in Uganda.. USAID-AIMS paper (Washington, D.C.: Management of Systems International).

Bose, B. (2017). The impact of microfinance on employees of dairy sector: a study in kottayam district, kerala.

Brau, J. C., Hiatt, S., \& Woodworth, W. (2009). Evaluating impacts of microfinance institutions using Guatemalan data. Managerial Finance, 35(12), 953-974.

Brau, J. C., Hiatt, S., \& Woodworth, W. (2009). Evaluating impacts of microfinance institutions using Guatemalan data. Managerial Finance, 35(12), 953-974.

Bagozzi, R. R., Yi, Y., \& Philipps, L. W. (1991). Assessing construct validity in organizational research. Administrative Science Quarterly, 36, 421-458.

CGAP (2003). Assessing the relative poverty of microfinance clients", CGAP, available at: www.cgap.org/docs/TechnicalTool_05_overview.pdf (accessed 3 November).

Chowdhury, A. M. R. \& Bhuiya, A. (2001). Do Poverty Alleviation Programmes Reduce Inequity in Health: Lessons from Bangladesh. in Poverty Inequity and Health, ed. D.Leon and G. Walt (Oxford: Oxford University Press)

Coleman, B. E. (1999). The impact of group lending in Northeast Thailand. Journal of development economics, 60(1), 105-141.

Chin, W. W. (2010). How to write up and report PLS analyses. In V.Esposito Vinzi, W.W.Chin, J.Henseler, \& H.Wang (Eds.), Handbook of partial least squares: Concepts, methods and application. New York: Springer, 645-689

Coleman, B. E. (1999). The Impact of group lending in Northeast Thailand. Journal of Development Economics, vol. 60, pp.105-141.

Copestake, J. (2002). Inequality and the Polarizing Impact of Microcredit: Evidence from Zambia's Copperbelt. Journal of International Development 14: 743-755. 
Crépon, B., Devoto, F., Duflo, E., \& Parienté, W. (2015). Estimating the impact of microcredit on those who take it up: Evidence from a randomized experiment in Morocco. American Economic Journal: Applied Economics, 7(1), 123-150.

Das, K.. S. (2012). Socio-Economic Empowerment of Women through SHG-Banking Linkage Programme: A Boon for Development. International Journal of Management \& Business Studies, 2(1), pp: 39-46.

De Goey, H. (2012). The social impact of microfinance: what changes in well-being are perceived by women group borrowers after obtaining a group loan?: A participatory rural appraisal in Dar es Salaam Region, Tanzania.

Dunford, C. (2006). Evidence of microfinance's contribution to achieving the Millennium Development Goals. Paper presented at the Global Microcredit Summit, Halifax, Nova Scotia, Canada. 12-15 November.

Durrani, M. K. K., Usman, A., Malik, M. I. \& Ahmad, S. (2011). Role of micro finance in reducing poverty: A look at social and economic factors. International Journal of Business and Social Science, vol. 2, no. 21, pp. 138-44.

Farag, N. M. (2011). Microfinance and poverty alleviation a case study of Al-Darb AlAhmar district in Cairo, Egypt.

Fofana, N.B., Antonides, G., Niehof, A., \& van Ophem, J. A. C. (2015). How microfinance empowers women in Côte d'Ivoire. Review of Economics of the Household, $1-19$.

Ghalib, A. K., Malki, I. \& Imai, K. S. (2011). The impact of microfinance and its Role in Easing Poverty of Rural Households: Estimations from Pakistan. Discussion Paper Series, Research Institution for Economics and Business Administration, Kobe University

Gill, I. S., Revenga, A., \& Zeballos, C. (2016). Grow, invest, insure: A game plan to end extreme poverty by 2030. The World Bank.

Goldberg, N. (2005). Measuring the impact of microfinance: Taking stock of what we know. Washington DC: Grameen Foundation, USA.

Harber, C. (2002). Education, democracy and poverty reduction in Africa. Comparative Education, 38(3), 267-276.

Henry, C., Sharma, M., Lapenu, C. \& Zeller, M. (2003). Microfinance poverty assessment tool. CGAP, available at: www1.worldbank.org/publications/pdfs/15674frontmat.pdf (accessed 3 January 2004).

Hair, J. F., Ringle, C. M., \& Sarstedt, M. (2013). Partial least squares structural equation modeling: Rigorous applications, better results and higher acceptance. Long Range Planning46(2), 1-12

Holvoet, N. (2004). Impact of microfinance programs on children's education. ESR Review, 6(2), 27.

Imai, K. S. \& Azam, M. S. (2012), Does microfinance reduce poverty in Bangladesh? New evidence from household panel data. Journal of Development studies, vol. 48, no. 5 , pp. 633-53

Islam, A. \& Choe, C. (2013). Child labor and schooling responses to access to microcredit in rural Bangladesh', Economic Inquiry, vol. 51, no. 1, pp. 46-61.

Joshi, P., \& Giri, A. K. (2016). Economic and Social Impact of Micro Finance Programs: An Empirical Study of SHGs in Rajasthan, India. IPE Journal of Management, 6(1), 131. 
Kaboski, J. P., \& Townsend, R.M. (2011). A structural evaluation of a large scale quasi experimental microfinance initiative. Econometrica, 79(5), 1357-1406

Kaboski, J. P. \& Townsend, R. M. (2012). The impact of credit on village economies. American economic journal. Applied economics, vol. 4, no. 2, p. 98.

Karim, R. (2017). Socioeconomic Impacts of Microfinance Programs in the Development of Bangladesh.

Khandkar, S. R., \& Faruqee, R. R. (2003). The impact of farm credit in Pakistan. Journal of Economics. Vol. 28. p. 197-213.

Khandker, S. (2003). Micro-finance and Poverty: Evidence Using Panel Data from Bangladesh. World Bank Policy Research Paper 2945, World Bank, Washington

Khandker, S. R., \& Koolwal, G. B. (2016). How has microcredit supported agriculture? Evidence using panel data from Bangladesh. Agricultural Economics, 47(2), 157-168.

Kono, H., \& Takahashi, K. (2010). Microfinance revolution: its effects, innovations, and challenges. The Developing Economics, 48, 15-75.

Li, X., Gan, C. \& Hu, B. (2011). The welfare impact of microcredit on rural households in China. The Journal of Socio-Economics, vol. 40, no. 4, pp. 404-11.

Littlefield, E., Morduch, J. \& Hashemi, S. (2003). Is microfinance an effective strategy to reach the Millennium Development Goals? , Focus Note, vol. 24, no. 2003, pp. 1- 11.

Maldonado, J. H. \& González-Vega, C. (2008). 'Impact of microfinance on schooling: Evidence from poor rural households in Bolivia. World Development, vol. 36, no. 11, pp. 2440-55.

McCulloch, N., \& Baulch, B. (2000). Simulating the impact of policy upon chronic and transitory poverty in rural Pakistan. The Journal of Development Studies, 36(6), 100-130.

McKernan, Signe-Mary (2002). The Impact of Micro-Credit Programs on Selfemployment Profits: Do Non-credit Program Aspects Matter? The Review of Economic and Statistics 84(1): 93-115.

McKernan, S. M. (2002). The Impact of Micro-Credit Programs on Self-employment Profits: Do Non-credit Program Aspects Matter?. The Review of Economic and Statistics 84(1): 93-115.

Mina, M. S. \& Alam, S. S. (1995). Impact of NGO activities on the development of rural economy of Bangladesh: A case study. The Journal of Finance and Banking, University of Dhaka, Vol.4, pp.20-38.

Mknelly, B. \& Dunford, C. (1998). Impact of Credit with Education on Mothers and Their Young Children's Nutrition (Ghana). Freedom from Hunger Research Paper No.4

MKNelly, B., Watetip, C., Lassen C. A. \& Dunford, C. (1996). Preliminary evidence that integrated financial and educational services can be effective against hunger and malnutrition. Freedom from Hunger Research Paper no. 2, Freedom from Hunger, April. Mohindra, K., Haddad, S. \& Narayana, D. (2008). International Journal for Equity in Health', International journal for equity in health, vol. 7, p. 2.

Morduch, J., Hashemi, S., \& Littlefield, E. (2003). Is microfinance an effective strategy to reach the millennium development goals? Focus Note 24 Washington, DC: Consultative Group to Assist the Poor.

Nawaz, S. (2010). 'Microfinance and poverty reduction: evidence from a village study in Bangladesh. Journal of Asian and African studies, vol. 45, no. 6, pp. 670-83. 
Henseler, J., Ringle, C. M., \& Sarstedt, M. (2015). A new criterion for assessing discriminant validity in variance-based structural equation modeling. Journal of the academy of marketing science, 43(1), 115-135.

Nghiem, H. S., Coelli, T. \& Rao, P. (2007). The welfare effects of microfinance in Vietnam: Empirical results from a quasi-experiment survey. Paper contributed to the 51st Annual Conference of the Australian Agriculture and Resources Economics Society. 1316 February 2007, Queenstown, New Zealand.

Nghiem, S, Coelli, T \& Rao, P. (2012). Assessing the welfare effects of microfinance in Vietnam: Empirical results from a quasi-experimental survey. vol 48, no. 5, pp 619-632.

Noreen, U., Imran, R., Zaheer, A. \& Saif, M. I. (2011). Impact of Microfinance on Poverty: A Case of Pakistan. World Applied Sciences Journal Vol.12, pp.877- 883

Panjaitan-Drioadisuryo, Rositan, D. M. \& Kathleen, C. (1999). Gender, SelfEmployment, and Microcredit Programs: An Indonesian Case Study. Quarterly Review of Economics and Finance, Vol. 39

Pitt, M. M., \& Khandker, S. R. (1998). The impact of group-based credit programs on poor households in Bangladesh: Does the gender of participants matter?.Journal of political economy, 106(5), 958-996.

Pitt, M. M. \& Khandker, S. R. (1998). The impact of group-based credit programs on poor households in Bangladesh: Does the gender of participants matter? Journal of political economy, vol. 106, no. 5, pp. 958-96.

Premchander, S. (2003). NGOs and local MFIs-how to increase poverty reduction through women's small and micro-enterprise, Elsevier Science Limited Futures, 35(4), pp: 361-378.

Rahman, M. W., Luo, J., \& Minjuan, Z. (2015). Welfare Impacts of Microcredit Programmes: An Empirical Investigation in the State- Designated Poor Counties of Shaanxi, China. Journal of International Development, 27(7), 1012-1026.

Remenyi, J. \& Benjamin, Q. Jr. (2000). Microfinance and Poverty Alleviation: Case Studies from Asia and the Pacific. New York: Pinter Publishers, Ltd., 79: 131-34; 25364.

Roy, I., \& Biswas, P. (2016). Role of Microcredit on the Education: A Study on NGOs in Bangladesh. Asian Business Review, 6(2), 105-110.

Saboor, A., Husain, M. \& Munir, M. (2009). Impact of Micro Credit in Alleviating Poverty: An Insight from Rural Rawalpindi, Pakistan. Pakistan Journal of Life and Social Science. 7(1): 90-97

Sebstad J, Chen, G. (1996). Overview of studies on the impact of microenterprise credit. Report submitted to USAID assessing the impact of microenterprise services (AIMS), June.

Sen, A. K. (1999). Development as freedom, New Delhi: Oxford University Press

Shimamura, Y \& Lastarria-Cornhiel, S 2010, 'Credit program participation and child schooling in rural Malawi', World Development, vol. 38, no. 4, pp. 567-80.iversity of Manchester.

Shirazi, N. S. (2012). Targeting and Socio-Economic Impact of Microfinance: A Case Study of Pakistan. Islamic Economic Studies, 20(2), 1-28. 
Shirazi, N. S. (2012). Targeting and Socio-Economic Impact of Microfinance: A Case Study of Pakistan. Islamic Economic Studies, 20(2), 1-28.

Singh, H. R., \& Singh, N. D. (2014). An Impact Assessment of Microfinance: A Case Study of Socio-Economic Empowerment of SHG Members in Manipur (India). ParipexIndian Journal of Research, 3(1), 141-147.

Stark, L., Kassim, N., Sparling, T., Buscher, D., Yu, G., \& Boothby, N. (2015). Assessing the impact of microfinance programming on children: an evaluation from post- tsunami Aceh. Disasters, 39(2), 295-315.

Swope, T. (2005). Microfinance and Poverty Alleviation. Available at: www.rollins. edu/olin/rurj/mpa.pdf.

Tarozzi, A., Desai, J., \& Johnson, K. (2015). The impacts of microcredit: Evidence from Ethiopia. American Economic Journal: Applied Economics, 7(1), 54-89.

Toindepi, J. (2016). Investigating a best practice model of microfinance for poverty alleviation. International Journal of Social Economics, 43(4), 346-362.

Tu, T. T. T., Ha, N. P., \& Yen, T. T. H. (2015). Socio-economic Impact of Rural Credit in Northern Vietnam: Does It Differ between Clients Belonging to the Ethnic Majority and the Minorities?. Asian Social Science, 11(10), 159.

UNDP (2001). Policy issues: Part I., available at: www.undp.org/dpa/publications/ choicesforpoor/ENGLISH/CHAP02.PDF (accessed 4 January 2004).

Verpoorten, M. (2009). Household coping in war- and peacetime: cattle sales in Rwanda, 1991-2001, Journal of Development Economics 88, 67-86.

World Bank (2011). Conflict, Security and Development, World Bank, Washington, DC. World Bank (2016). World development report 2016: Digital dividends. Washington D. C: World Bank.

Wright, G. (2000). Microfinance systems: Designing quality financial services for the poor. Zed Books.

Wydick, W. B.e (1999). The effect of microenterprise lending on child schooling in Guatemala. Economic Development and Cultural Change 47, 853-869.

Zaman, H. (1999). Assessing the poverty and vulnerability impact of micro-credit in Bangladesh: A case study of BRAC.

Zeller, M., Sharma, M., Henry, C. \& Lapenu, C. (2003). Operational method for assessing the Poverty Outreach of Performance of Development Projects", ILO, Geneva, available at: www.iaae-agecon.org/conf/durban_papers/papers/004.pdf (accessed 8 February 2004). 